\title{
Research Article: Impact of counseling on awareness and adoption level of rural women regarding drudgery reducing techniques
}

\section{KULVIR KAUR}

Article Chronicle: Received :

11.03.2017;

Revised :

28.03.2017;

Accepted :

11.04.2017

KeY Words:

Drudgery,

Counseling, Adoption advantage of gravity. 266-269.
SUMMARY : Women always involve themselves in multifarious activities and spend most of their time in performing home related activities under stressful work conditions and changes postures on own ways such as bending, standing, squatting, sitting without knowing the health hazards of those. So the present study was undertaken to assess the adoption of correct techniques before and after intervention of drudgery reducing techniques. It was found that only 10 per cent respondents were having knowledge of keeping back in erect position and 40 per cent rural women had knowledge of using smaller movements of hands. After counseling, cent per cent respondents had acquired knowledge of storing of objects at proper heights. Twenty-six per cent respondents had lack of interest in taking

How to cite this article : Kaur, Kulvir (2017). Impact of counseling on awareness and adoption level of rural women regarding drudgery reducing techniques. Agric. Update, 12(2): 266-269; DOI : 10.15740/HAS/AU/12.2/
Author for correspondence :

\section{KULVIR KAUR}

Directorate of

Extension Education,

Punjab Agricultural

University, LUDHIANA

(PUNJAB) INDIA

Email:kulvirkaur70@pau.edu 